\title{
A new distributed rainfall-runoff model (DR2) based on soil saturation and runoff cumulative processes
}

\author{
M. López-Vicente ${ }^{a, b, *}$, A. Navas ${ }^{\text {a }}$ \\ ${ }^{a}$ Dept. of Soil and Water, Experimental Station of Aula Dei, EEAD-CSIC, Postal Box 13034, 50080 Zaragoza, Spain \\ ${ }^{b}$ Dept. of Earth and Environmental Science, Katholieke Universiteit Leuven, GEO-INSTITUTE, Celestijnenlaan 200 \\ E, 3001 Heverlee-Leuven, Belgium \\ * Correspondence: Dr. Manuel López-Vicente. mvicente@eead.csic.es
}

\begin{tabular}{ll}
\hline---- Received & 27 April 2011 \\
---- Received in revised form-I & 16 November 2010 \\
--- Received in revised form-II & 1 December 2010 \\
---- Received in revised form-III & 5 December 2010 \\
---- Accepted for publication in Agricultural Water Management & 6 December 2011 (DOI: 10.1016/j.agwat.2011.12.007) \\
\hline--- Available online in Elsevier & 27 December 2011 \\
---- Published in Agricultural Water Management 104: 128-141 & February 2012 \\
\hline
\end{tabular}

Summary: One important issue in agricultural management and hydrological research is the assessment of water stored during a rainfall event. In this study, a new GIS-based rainfall-runoff model is presented to estimate soil moisture status $(S M S)$ for each month of the year after an average rainfall event with maximum intensity. The new model computes the volume of actual available water $\left(W_{a a}\right)$ downwards from divides, taking into account the different configurations of the upslope contributing area, infiltration processes and climatic parameters. Results show that the spatial distribution of the different soil types is the main controlling factor in the initiation of runoff and, to a lesser extent, the antecedent topsoil moisture and the volumetric water content of the soil at saturation. Monthly $W_{a a}$ and $S M S$ maps and Palmer $Z$-indexes present similar spatial patterns, although the values and the extension of the different dry and wet categories varied considerably. Predominant wet conditions occurred in May, September, October, November and December and dry conditions appeared in February, March and July. The wettest conditions took place in gently sloping areas, 
according to the topographic wetness index. Maps based on Palmer Z-indexes match very closely the $S M S$ patterns predicted by the DR2 model from January to September, but the similarity was poor from October to December. Spatial predictions with the new model identify the different sub-categories of soil wetness for each soil type in greater detail. The DR2 model seems to be of interest to monitor humidity variations and trends in time and space and to provide valuable information for sustainable soil and water resource management.

Keywords: Actual available water; Soil moisture status; DR2 model; Topsoil saturation; Cumulative Runoff; Soil Type; Palmer Z-index

\section{Introduction}

An aridity index is a climatological indicator that is defined in terms of low average precipitation, available water, or humidity and is a permanent feature of a region, while a drought index reflects a temporary reduction in precipitation or available water from its normal level (World Meteorological Organization, 1975). Normal values are defined from the principles of water balance between moisture supply and demand without considering man-made changes (Karl, 1986). Aridity indicators identify, locate or delimit regions that suffer from a deficit of available water, a condition that can severely affect the effective use of the land for agriculture, water harvesting (Thomas, 2008) or stock-farming.

A drought index enables measuring areas of abnormal wetness and dryness within a study site with persistently normal precipitation, according to the antecedent precipitation, moisture supply and moisture demand (Heim, 2002). The average crop yield under rain-fed conditions is still highly controlled by drought and wet periods, 
such as in India (Lal, 2008), but also in Europe the heat and drought in 2003 significantly reduced primary productivity (Ciais et al., 2005). In the short term, the consequence of drought periods or trends is a decline in crop yield (Diodato and Bellocchi, 2008) while a long term consequence is a decrease in water resources. The over-exploitation of agricultural lands in semi-arid regions calls for accurate assessment of the moisture status of the soil. Recent studies have shown that semi-arid and arid environments present a higher vulnerability to projected climate change than humid environments in relation to hydrological processes and vegetation productivity (Zhongmin et al., 2009). Moreover, studies of long-term episodes $\left(10^{2}-10^{3} \mathrm{yr}\right)$ of net erosion and deposition in Western Mediterranean beach deposits found a positive correlation between higher erosion rates and increased aridity conditions (Goy et al., 2003).

Several equations exist to estimate the humidity status of a soil. Water balance indexes are complex and consider water supply (precipitation), demand (evapotranspiration) and loss (runoff). Palmer's indexes belong to this category and include the Palmer Z-Index (short-term drought on a monthly scale), the Palmer Crop Moisture Index (CMI) (short-term drought on a weekly scale and used in agriculture during the growing season), and the Palmer Drought Severity Index (PDSI) (long-term drought-inducing circulation patterns) (Palmer, 1965). Another index is the topographic wetness index $(T W I)$ that combines local upslope contributing area and slope, and which is commonly used to quantify topographic control on hydrological processes (Sørensen et al., 2006) although this index does not consider precipitation data. The wide variety of disciplines affected by soil dryness, the high number of drought definitions (hydrological, meteorological, or agricultural) (Dracup et al., 1980a) and its diverse geographical and temporal distribution, and the many drought scales operate on, make it 
difficult to develop either an accurate methodology to describe drought or an index to measure it (Wilhite and Glantz, 1985). Other drought indexes are the index of Dracup et al. (1980b), which uses long-term mean annual streamflow or runoff to characterize drought events, and the Surface Water Supply Index (SWSI) of Wilhite and Glantz, (1985). However, none of the above indexes offers a holistic approach to all the processes included in the humidity status of a soil, nor do their spatial and temporal scales allow for detailed mapping.

Climate models throughout the world are predicting an increase in global temperature and drought severity in some regions, such as the western United States (Cook et al., 2004) and the Iberian Peninsula (Vicente-Serrano et al., 2011). Given the potential economic loss related to drought conditions, scientists and policymakers need more accurate drought indicators to carefully evaluate possible trends and plan land conservation policies.

A critical point in the modelling process is the choice of the spatial resolution for hydrological and meteorological phenomena simulations (Spadavecchia and Williams, 2009). Some articles deal with humidity research in large-scale areas (e.g., Wang and Takahashi, 1999 in the Loess Plateau, China) and in some cases, with the assistance of remotely sensing images (e.g., Mallick et al., 2009). Previous studies on aridity indexes in Mediterranean countries have described that the effects of drought on the natural vegetation and agricultural crops vary largely between areas and also from month to month (Vicente-Serrano, 2007).

In this study, we present a new water balance rainfall-runoff model based on processes of soil saturation and conductivity, and cumulative runoff for the maximum rainfall intensity conditions during each month of the year and under different scenarios of infiltration and cumulative processes (saturated and non-saturated soils, and high and 
low upslope contribution). This model is spatially distributed and applied in a mediumsize catchment in NE Spain (Estaña Lakes catchment) as representative of the midmountainous rain-fed agricultural Mediterranean landscape. Values and maps of actual available water and soil moisture status are compared with the values calculated with the well-known Palmer Z-index for the study area. The equations and the proposed protocol of the new model are processed with GIS techniques in order to be of interest for both experts and non-experts in the different topics of soil management.

\section{Materials and methods}

\subsection{Study area}

The Estaña Lakes catchment is a medium-size watershed (246 ha) located in the External Ranges of the Central Spanish Pre-Pyrenees and within the Ebro Basin (Fig. 1a). This study site is divided in fifteen endorheic sub-catchments where seventeen dolines appear and it includes three fresh-water lakes (total area of 17 ha). These lakes and their surrounding vegetation are under regional protection since 1997 and are included in the European NATURA 2000 network as Site of Community Importance (SCI). Elevation ranges between 676 and $896 \mathrm{~m}$ a.s.l. and the mean slope steepness is $19.5 \%$. Steep slopes (slope steepness higher than $22.5 \%$ ) occupy $20 \%$ of the study area whereas gentle slopes (slope steepness lower than $8 \%$ ) cover $33 \%$.

The study site has a relatively long history (since the $10^{\text {th }}$ century) of human occupation, agricultural practices and water management (Morellón et al., 2008), with increasing population along the $19^{\text {th }}$ century and a continuous depopulation trend since then (Morellón et al., 2009). The landscape is representative of the typical former rainfed Mediterranean agro-ecosystem where small patches of natural and anthropogenic areas are heterogeneously distributed. Cropland of winter barley, pasture and orchards 
cover $31 \%$ of the study area, whereas forest and scrubland occupy $67 \%$. The parent material of the soils in the study area corresponds to Mesozoic gypsiferous marls, dolomites, limestones, and sparse saline deposits. Karstic processes partially dominate the evolution of this landscape where seventeen sinkholes and two uvalas appears (López-Vicente et al., 2009a). Machín et al. (2008) distinguished six types of soils being Calcisols (covering $32 \%$ of the total surface), Leptosols (32\%) and Regosols (23\%) which are the main types, whereas Gleysols (4\%), Gypsisols (5\%) and Vertisols (3\%) only occupy a small part of the catchment. Calcisols and Leptosols are associated to limestones, and Gypsisols, Regosols and Vertisols to clayish materials. Texture is mainly silty loam and in some parts silty clay loam. Gleysols are developed on clay materials where the water table is seasonally near the soil surface and appear around the lakes. The different soil types present a complex spatial distribution as a consequence of the intricate geology and topography.

Climate is continental Mediterranean with two humid periods, one in spring (April and May) and a second in autumn (September and October) and a dry summer with rainfall events of high intensity (average maximum rainfall intensity in $30 \mathrm{~min}, I_{30 \mathrm{max}}$, higher than $30 \mathrm{~mm} \mathrm{~h}^{-1}$ between May and October) (López-Vicente et al., 2008). The study site is located between the semi-arid areas of the Ebro valley to the south and the humid areas of the Pyrenees to the north. Average annual precipitation at the weather station of Canelles ( $8 \mathrm{~km}$ to the southeast of the study area) was $520 \mathrm{~mm}$ for the reference period 1961-1990 considered by the World Meteorological Organization, whereas the average precipitation during the last ten years (1999-2008) was 13\% lower (453 mm) (Fig. 1b). Annual precipitation has a strong inter-annual oscillation. The average annual potential evapotranspiration is $1237 \mathrm{~mm}$ at the Barbastro weather station (33 $\mathrm{km}$ to the west of the study area) (Fig. 1c). Low summer precipitation can cause 
summer droughts and long periods of low rainfall depth can cause severe damage in natural vegetation and crops, and reduce the volume of available water in the lakes. From an average number of 73 annual rainfall events only 12 had precipitation above $12.7 \mathrm{~mm}$ and can be considered as erosive events (Renard et al., 1997). Weather, topography, land uses and tillage practices in the Estaña catchment are representative of rain-fed areas in Mediterranean mountainous agro-ecosystems.

\subsection{Conceptual basis of the distributed rainfall-runoff model (DR2)}

The new DR2 model computes for each month of the year the water balance of the soil and estimates the soil moisture status $(S M S)$ as the ratio between the depth of actual available water $\left(W_{a a}, \mathrm{~mm}\right)$ and potential reference evapotranspiration $(E T, \mathrm{~mm})$ :

$$
S M S=\frac{W_{a a}}{E T}
$$

where $W_{a a}$ is defined as the total depth of water that is stored and infiltrated in the soil profile during an average storm event for each month. Water inputs are assumed to be the sum of the direct rainfall depth and of the upslope contributing runoff, and moisture demand is computed as equal to potential evapotranspiration. Although several rainfallrunoff models exist, such as the CASC2D (Julien and Saghafian, 1991) or the TOPMODEL (Beven and Kirkby, 1979), they are not usually run to characterize the humidity status of the soil. In this study a new sequence of calculations in three steps is established to estimate the depth of $W_{a a}$ at each pixel in any study site (Fig. 2). In the first step the unsaturated and saturated pixels by direct rainfall (no runoff contribution) are distinguished. In the second step unsaturated pixels with and without upslope contribution of runoff are discriminated. Finally, the upslope contributing runoff is calculated for the unsaturated and saturated pixels as a function of the effective depth of 
cumulative runoff. Following this step-by-step approach five different situations are distinguished. Values of $W_{a a}$ are spatially calculated with GIS techniques.

\subsection{Estimation of overland flow at raster cell}

Soil only becomes saturated during a storm event or when the water table reaches the soil surface. Time to ponding $(T p, \mathrm{~s})$ is the time until the surface of the soil is saturated under a rainfall intensity greater than the saturated hydraulic conductivity $\left(K_{f s}, \mathrm{~cm} \mathrm{~s}^{-1}\right)$ (Esteves et al., 2005). Before $T p$ all the water infiltrates, beyond $T p$ only a fraction goes into the soil profile and the other part becomes runoff. Time to ponding depends on soil infiltration properties, rainfall intensity and the antecedent soil moisture content and can be calculated as a function of saturated hydraulic conductivity $\left(K_{f s}, \mathrm{~cm} \mathrm{~s}^{-1}\right)$ and soil sorptivity $\left(S_{p}, \mathrm{~cm} \mathrm{~s}^{-0.5}\right)$ (White and Sully 1989). Hogarth et al. (1991) proposed that time to ponding $(T p, \mathrm{~s})$ has a minimum and a maximum time and state that the average value can be calculated as:

$$
\begin{aligned}
& \frac{1}{2} \frac{S_{p}{ }^{2}}{K_{f s}} \ln \left(\frac{I}{I-K_{f s}}\right) \leq T p \leq \frac{1}{2} \frac{S_{p}{ }^{2}}{I-K_{f s}} \\
& S_{p}=\sqrt{2(\Delta \theta) \phi} \\
& \Delta \theta=\theta_{S}-\theta_{0}
\end{aligned}
$$

where $I\left(\mathrm{~cm} \mathrm{~s}^{-1}\right)$ is the rainfall intensity, $\phi$ is the matrix flux potential $\left(\mathrm{cm}^{2} \mathrm{~s}^{-1}\right)$ of each soil type and $\theta_{S}(\%$ vol. $)$ and $\theta_{0}(\%$ vol. $)$ are the saturated and initial volumetric water content, respectively. The saturated volumetric water content is the maximum amount of water that can be stored within the soil and the initial water content is the volume directly measured in the field (antecedent topsoil moisture).

Time to ponding is calculated in each point of topsoil moisture measurement for a characteristic rainfall event for a month (i.e. average maximum intensity). Then, the 
potential overland flow per raster cell for each month $m\left(Q_{0 m}, \mathrm{~mm}\right)$ is estimated as a function of the depths of monthly rainfall $\left(R_{m}, \mathrm{~mm}\right)$ and rainfall to ponding $\left(R p_{m}, \mathrm{~mm}\right)$ :

$$
Q_{0 m}=R_{m}-\left(R p_{m} e_{m}\right)=R_{m}-\left(T p_{m} I_{m} e_{m}\right) 10
$$

where $T p_{m}$ is the monthly time to ponding (s), $I_{m}$ is the monthly rainfall intensity (cm s${ }^{1}$ ) and $e_{m}$ is the monthly number of rainfall events. Equation (5) uses monthly average values of rainfall, number of rainfall events and rainfall intensity. The DR2 model runs on a monthly time step and intends to assess the average wetness status of the soil and not to calculate the humidity of the soil after each rainfall event.

\subsection{Estimation of the effective runoff and actual available water ( $\left.W_{a a}\right)$}

Values of potential overland flow per raster cell at each measurement point were interpolated for the whole catchment and month with the Spline interpolator method that fits a minimum-curvature surface through the input points. Once the map of $Q_{0 m}$ is obtained the potential cumulative runoff $\left(C Q_{0 m}\right)$ is calculated with a combined flow accumulation algorithm that runs as a multiple flow algorithm from the catchment divides to a threshold value that is associated with the beginning of the gullies (concentrated flow). From this threshold value on overland flow is computed with a simple flow algorithm. The usefulness of cumulative algorithms to study hydrological processes at catchment scale was proved by several authors (e.g., Borselli et al., 2008) and by López-Vicente and Navas (2010) for this study area. The effective cumulative runoff for each month $m\left(C Q_{e f f-m}\right)$ is calculated according to:

$$
C Q_{\text {eff }-m}=\left(C Q_{0 m}-K_{f s} T q_{m} e_{m}-S S_{\max } e_{m}\right) \sin S
$$

after considering the saturated hydraulic conductivity $\left(K_{f s}, \mathrm{~mm} \mathrm{~s}^{-1}\right)$ and the average duration of a storm after the soil becomes saturated till the end of the rainfall event for each month $m\left(T q_{m}, \mathrm{~s}\right)$ : 


$$
T q_{m}=T R_{m}-T p_{m}
$$

the maximum amount of water retained on the soil surface $\left(S S_{\max }, \mathrm{mm}\right)$ according to Driessen (1986):

$$
S S_{\max }=0.5 R G \frac{\sin ^{2}(S I G-S)}{\sin (S I G)} \frac{\cot (S I G+S)+\cot (S I G-S)}{2 \cos (S I G) \cos (S)}
$$

and the slope steepness ( $S$, radians). $T R_{m}(\mathrm{~s})$ is the total duration of an average storm event considering an average value of rainfall intensity for each month $m . R G(\mathrm{~mm})$ is the surface roughness, i.e. the maximum depth of the soil micro-relief, and $S I G$ (radians) is the surface furrow and ridge angle determined by tillage marks and microtopography. Finally, values of actual available water $\left(W_{a a}\right)$ and soil moisture status $(S M S)$ are estimated for each month following the comprehensive approach described in Fig. 2 and Eq. (1).

\subsection{Comparison of the new DR2 model with the Palmer Z-index}

The widely-used Palmer moisture anomaly index ( $Z$-index) is utilized in this study to quantify monthly dryness and wetness intensity for comparison with the values and maps of the SMS predicted with the DR2 model. The Palmer Z-index is a measure of surface moisture anomaly for a current month without consideration of the antecedent conditions (Trnka et al., 2009a). This index is much less sensitive to changes in calibration, and also has some desirable characteristics which may make it preferable to some agricultural and forest applications, i.e., it is more responsive to short-term moisture anomalies (Karl, 1986). The Palmer $Z$-index is defined as:

$$
Z_{m}=K d_{m}
$$

with

$$
d_{m}=P_{m}-\hat{P}_{m}
$$

and

$$
\hat{P}_{m}=\overline{E T_{m}}+\overline{R_{m}}+\overline{R O_{m}}-\overline{L_{m}}
$$


where $K$ is a climate weighting factor and is applied to yield indices with comparable local significance in space and time, and $d_{m}$ represents the deficit or surplus of moisture, adjusted for the seasonal changes in climate. $P_{m}$ is the total precipitation and $\hat{P}_{m}$ is the precipitation value climatologically appropriate for existing conditions for each month $m$. The $\hat{P}_{m}$ factor represents the water balance equation where $\overline{E T_{m}}, \overline{R_{m}}$ and $\overline{R O_{m}}$ are the long-term monthly averages of evapotranspiration, soil water recharge and runoff, respectively. Palmer (1965) used a two-layer soil model consisting of a surface layer being the 'plow layer', and an underlying 'root zone', and defined $\overline{L_{m}}$ as the sum of soil water of the two layers available for evapotranspiration. He called this term 'potential loss of soil water to evapotranspiration' (for more detail, see Hu and Willson, 2000).

An empirical value, $K$, is used in the definition of the climate characteristic. According to Palmer (1965) extremely dry Z-index values are defined as those at or below -2.75 . Conversely, positive values indicate increasing levels of moisture and runoff with values at or above 3.50 indicating extreme wetness (Table 1). Extremely dry and extremely wet $Z$-index values correspond to a frequency of $2 \%$. According to Ghioca (2009) the expected $2^{\text {nd }}$ percentile of the $Z$-index values is -2.75 and the expected $98^{\text {th }}$ percentile is 3.50 . Using these two expected values of the $Z$-index in a definition of the ratio leads to the following formula for $K$ :

$$
K=\left\{\begin{array}{l}
\left(-2.75 / 2^{\text {nd }} \text { percentile }\right) K_{m} \text { if } d<0 \\
\left(3.50 / 98^{\text {th }} \text { percentile }\right) K_{m} \text { if } d \geq 0
\end{array}\right.
$$

where $d$ represents the deficit or surplus of moisture, and $K_{m}$ is a climate weighting factor derived by Palmer (1965) as follows: 


$$
K_{m}=\frac{17.67}{\sum_{m=1}^{12} \overline{D_{m}} K_{m}^{\prime}} K_{m}^{\prime}
$$

with $K^{\prime}{ }_{m}$ another climate weighing factor given by:

$$
K_{m}^{\prime}=1.5 \log _{10}\left(\frac{\frac{\overline{P E_{m}}+\overline{R_{m}}+\overline{R O_{m}}}{\overline{P_{m}}+\overline{L_{m}}}+2.8}{\overline{D_{m}}}\right)+0.5
$$

where $\overline{D_{m}}$ is the average moisture departure for the appropriate month (comparing expected precipitation to the actual precipitation) and $\overline{P E_{m}}$ is the average potential evapotranspiration.

In this study the estimated values of the Palmer $Z$-index for the different months of the year are scaled so that they fit into the seven categories shown in Table 1 to allow for comparisons across time and space. Several approaches of self-calibrating Palmer's drought indices exist to represent a more appropriate means of comparing spatial relationships between areas of differing moisture climates (Trnka et al., 2009b). However, the small size of the study area $\left(2.5 \mathrm{~km}^{2}\right)$ makes no necessary any spatial correction in the obtained values.

\subsection{Field measurements and weather data}

A frequency-domain probe (Delta-T Theta Probe ML2x) was used to measure topsoil moisture $\left(\theta_{0}\right.$ in Eq.(4)). This device has a portable/handheld reading unit for field measurements and has a configuration of two rods that are inserted in the soil up to 8 cm depth (for more details see López-Vicente et al., 2009b). Soil moisture was measured in a field work comprising the years 2005 (February, August and December) and 2006 (May). A total of 236 measurement points were established following a regular net with a distance of $100 \mathrm{~m}$ between points that entirely covers the Estaña 
catchment. Three values of $\theta_{0}$ were measured at each control point and the average value was estimated as the representative value. Although antecedent top soil moisture is a monthly required input of the DR2 model only seasonal measurements were performed due to operational cost restrictions and the same record was used for the three months of the same season.

A field survey was carried out and 236 soil samples were collected in the same points where topsoil moisture measurements were done, which provided one soil sample collected about every 1 ha. The volumetric water content at saturation $\left(\theta_{S}\right)$ was measured in the laboratory and values were used in Eq. (4). Values of saturated hydraulic conductivity and matrix flux potential, $K_{f s}$ and $\phi$ in Eq. (2) and (3), respectively, correspond to those measured by López-Vicente and Navas (2009) with the Guelph Permeameter for the different soil types.

Climatic data of rainfall intensity $(I)$, total rainfall depth $(R)$ and the number of erosive rainfall events $(e)$ used in the DR2 model corresponds to those recorded at the Canelles weather station since October 1997 till December 2008 (Fig. 1b and 1c). This station is located south-eastern of the study area at a distance of $9 \mathrm{~km}$ and records precipitation values each 15 minutes since October 1997, daily values since 1955 and monthly values since 1940. There are other weather stations surrounding the study area but only with daily records. Values of water loss from the soil and evapotranspiration, $\overline{L_{m}}, \overline{E T_{m}}$ and $\overline{P E_{m}}$ correspond to those calculated by López-Vicente et al. (2005) with the CropSyst 4.04.14 cropping simulator program. Values of $\overline{D_{m}}$ (Eqs. (13) and (14)) were calculated from the total dataset of monthly precipitation at the Canelles weather station from the basis of the reference period 1961-1990 proposed by the World Meteorological Organization. Values of soil water recharge and runoff, $\overline{R_{m}}$ and $\overline{R O_{m}}$ in Eq. (11) have 
been equaled in this study to the monthly values of infiltrated water and effective cumulative runoff, respectively, as described in Fig. 2 and Eq. (6). All input values, the interpolation and mathematical operations and the output maps were done with the ArcView GIS 3.2 and ArcGIS 9.0 applications at a spatial resolution of 5 x $5 \mathrm{~m}$ of cell size.

\section{Results and discussion}

\subsection{Time to ponding and overland flow}

Measured antecedent topsoil moisture, $\theta_{0}$, presented the highest values in autumn and the lowest in summer, with average values of 17.7 and $10.7 \%$ vol., respectively, for the whole Estaña catchment (Fig. 3). The variability of the values obtained for $\theta_{0}$ was greater in spring and winter than in summer and autumn. Values of $\theta_{0}$ showed high spatial variations for each season and also between the different seasons, thereby setting a spatial pattern that is a function of the different soil types and topographic scenarios of slope and aspect as described for this catchment by López-Vicente et al. (2009b). These authors found that the highest values of relative topsoil moisture appeared in spring, summer and winter in the steep northern slopes, whereas no comprehensive spatial pattern took place in autumn.

Time to ponding, $T_{p}$, was calculated for each soil type and month and under the scenarios of both an average storm event (mean rainfall intensity, $I_{30 \text { mean }}$ ) and the heaviest storm event (maximum rainfall intensity, $I_{30 \max }$ ) in each month (Table 2 ). $T_{p}$ varied greatly between soil types and within the same soil type in the different seasons and months. For an average storm event, Leptosols did not reach saturation in any season, Calcisols only became saturated in summer and early autumn, and Regosols in late spring, summer and early autumn. However, Calcisols and Regosols became 
saturated in spring, summer and autumn during the heaviest storm event registered in the study area, whereas runoff only appeared in Leptosols in May, August, September and October during the heaviest storm event. The high values of saturated hydraulic conductivity in Leptosols, Calcisols and Regosols and the low values of rainfall intensity registered in some of the months explained these results. Gleysols and Gypsisols always became saturated, as did Vertisols except in March and December. Because of the lack of data on the position of the water table and its influence on the processes of soil saturation in the study area, the assessment of time to ponding was less accurate, especially in Gleysols, where the water table is close to the soil surface due to their proximity to the lakes. The relationship between runoff generation and water table position was underlined by Latron and Gallart (2008) in a study of a small catchment in the eastern Spanish Pyrenees during dry and wet conditions, and by Grabs et al. (2009) in a catchment with numerous wetlands in northern Sweden. To overcome this limitation, further research should include measurements of the water table level and of the antecedent moisture content at different depth intervals.

Values of potential overland flow per raster cell, $Q_{0 m}$, during maximum rainfall intensity varied notably in terms of time and space. When rainfall intensity is high (May, August, September and October), potential runoff was predicted along the whole catchment and variability of $Q_{0 m}$ was very low, whereas areas with no runoff production appeared when rainfall intensity was low and variability of $Q_{0 m}$ values was high. A variance components analysis (Statgraphics ${ }^{\odot}$ ) shows that values of $Q_{0 m}$ are mainly explained by variations in the values of $K_{f s}\left(76 \%\right.$ of the variability of $\left.Q_{0 m}\right)$ and, to a lesser extent, by the values of the antecedent topsoil moisture $(23 \%)$ and the volumetric content of water of the soil at saturation $(1 \%)$. The runoff coefficients $\left(Q_{C}\right.$; percentage of runoff depth per raster cell from the total depth of rainfall) were calculated for the 
maximum rainfall intensity and estimated for the whole catchment and for the different soil types (Fig. 4). Values of $Q_{C}$ showed a strong variability during the different months of the year and important differences occurred between the different soil types for the whole year and for each month. Vertisols and Gypsisols presented high runoff coefficient values (over 70\%) for all months, whereas Calcisols, Leptosols and Regosols showed strong differences in their runoff coefficients for the different months (standard deviation around or higher than 40\%). Maximum surface storage capacity of the soil $\left(S S_{\max }\right.$ in Eq. (6) and (8)) within the different parts of the catchment ranged between 0 and $2.8 \mathrm{~mm}$ per month and thus this factor did not appear to be critical for runoff calculation.

Maps of effective cumulative runoff after the maximum rainfall intensity $\left(C Q_{\text {eff-m }}\right)$ presented similar spatial patterns during the different months and identified Regosols and Gypsisols as the main runoff production areas (Fig. 5). Maps of $C Q_{\text {eff- } m}$ also drew the main flow paths of the Estaña catchment and numerous outlets associated with the lakes and the bottom of the different endorheic sub-catchments and tally with the spatial location of the gullies and preferential areas of overland flow accumulation described in the geomorphic map by López-Vicente et al. (2009a). Values of effective cumulative runoff and areas without runoff production changed temporally as a function of rainfall intensity, infiltration rates and topography of the catchment. Areas with values of $C Q_{\text {eff- }}$ $m$ equal to zero appeared during the twelve months in those areas where infiltration rates are very high and in areas close to the headwaters, whereas runoff production changed temporally from zero to high values where infiltration rates presented values in the same range as the values of rainfall intensity.

\subsection{Soil moisture status (SMS)}


Maps of monthly actual available water after maximum rainfall intensity, $W_{a a}$ (Fig. 6), presented the same spatial pattern as the $C Q_{\text {eff-m }}$ maps, though values varied as a function of total rainfall depth and infiltration, and the five different scenarios of cumulative processes described in Fig. 2. The minimum value of $W_{a a}$ for each month was well correlated with the average values of precipitation (Pearson's $r=0.86$ ), whereas the mean values of $W_{a a}$ showed a close correlation with the values of maximum rainfall intensity (Pearson's $r=0.92$ ). Maximum values of $W_{a a}$ did not present significant correlation with climatic variables and were mainly controlled by processes of overland flow accumulation.

Maps of soil moisture status (Fig. 7) and their values were reclassified in seven wetness-dryness categories (Table 3) - the same number as defined in the Palmer Zindex - in order to facilitate their comparison. The spatial distribution of SMS values after the maximum rainfall intensity mainly mirrored the spatial pattern of $W_{a a}$ values for each month, although differences between the seven categories in the index highlighted the spatial and temporal changes in greater detail. Predominant wet conditions occurred in May, September, October, November and December (SMS scenario 1), whereas dry conditions appeared in February, March and July (SMS scenario 2). Drying-up conditions (SMS scenario 3) were identified in January and June and wetting-up conditions (SMS scenario 4) occurred in April and August. Each scenario is associated with different rainfall intensities and depths, topsoil moisture, and dominant runoff generation and accumulation processes. These different runoff generation process scenarios were recently described by Latron and Gallart (2008) in the small Can Vila catchment (NE Spain), where climate and topographic conditions are comparable to those in the Estaña catchment. According to the authors, under dry conditions, runoff was generated essentially as infiltration excess runoff in low 
permeable areas, whereas saturation excess runoff dominated during wetting-up and wet conditions.

As average annual values, dry conditions are found in $64 \%$ of the Estaña catchment surface, whereas humid and normal conditions take place in 30 and $6 \%$, respectively. The spatial SMS pattern was similar in February, March and December, when very low runoff coefficient values were obtained; similar spatial patterns also appeared in May, August, September and October, in accordance with the highest values of runoff coefficients.

The complexity of the spatial predictions in the DR2 model is controlled by several factors. SMS values changed between the different slope steepness of topographic surfaces, the wettest conditions occurring in gently sloping areas, whereas the driest conditions were found in steep slopes (Fig. 8). The annual percentage of soil surface under dry conditions ranged from 59 to 65 and $66 \%$ for gentle (slope steepness $S<8 \%$ ) to medium $(8 \%<S<22.5 \%)$ and steep slopes $(S>22.5 \%)$, respectively. These spatial patterns match the spatial distribution of the values for relative topsoil moisture $\left(\theta_{R}=\theta_{0} / \theta_{F C} 100\right.$; antecedent topsoil moisture in relation with soil moisture content at field capacity) and the topographic wetness index (TWI) (Fig. 7) calculated by LópezVicente et al., (2009b) in the Estaña catchment. Although the study area is included in a karstic system, no subsurface flow paths are known in this catchment. Therefore, we assume that the presence of karstic features do not compromise the use of this new GIS approach to measuring soil humidity.

$S M S$ values also presented clear differences among the different soil types (Fig. 7 and 9). Wet conditions were predicted in 57 and $48 \%$ of the study area in Vertisols and Regosols, respectively, whereas these percentages decreased progressively from $36 \%$ in Gypsisols to $29 \%$ in Gleysols, and to $22 \%$ in Calcisols and Leptosols. On a monthly 
basis, the same temporal patterns were observed in Calcisols and Leptosols and between Vertisols and Regosols. Dry conditions were predicted in February and March for all soil types except for Gypsisols, where wet conditions were predicted for these two months (Fig. 9). These results outline the importance of considering the spatial variability of the wetness status within each soil type, though saturated hydraulic conductivity is considered to be the same in each type. This variation can be explained by the spatial changes in the antecedent topsoil moisture content and the physiographic conditions in each pixel within the same soil type (Table 4). Detailed mapping of topsoil moisture and water deficit can provide valuable information for sustainable soil and water resource management in agro-climatic analysis, especially in rain-fed productive agricultural systems.

\subsection{Comparison with the Palmer Z-index}

Maps calculated with Palmer Z-index during maximum rainfall intensity (Fig. 10) showed a similar spatial pattern of soil dryness and wetness as the maps estimated with the new water balance model, although values using the Palmer $Z$-index were more extreme. Wet (extremely moist, very moist and moderately moist categories), normal range and dry (moderately dry, severely dry and extremely dry categories) areas identified with Palmer's index showed a perfect match with the areas predicted by the DR2 model within a percentage range between 93 and 99\% for the period January September and between 7 and 28\% for the period October - December (Fig. 11). Comparison between the Palmer index for drought and the water balance obtained with the new model indicated that the DR2 model presented the different dryness and wetness categories within each month and between the different months of the year in greater detail. On a monthly scale, a moderate correlation appeared in Calcisols 
(Pearson's $r=0.57)$ and Regosols $(r=0.58)$ and a fairly good correlation in Leptosols $(r=0.75)$. Moreover, differences in soil wetness within the same soil type were more prominent with the new model (Table 4), whereas in the Palmer Z-index maps, the processes of runoff accumulation appeared to be more significant. Therefore, the DR2 model seems to be of interest to monitor humidity variations and trends in time and space in Mediterranean landscapes, as Balling (1996) did with the Palmer Drought Severity Index in United States for the period 1895-1995.

Given the currently high technological development of GIS applications and the availability of detailed digital elevation models (DEMs) and datasets of soil properties, the DR2 model appears to be suitable for areas where significant changes in rainfall intensities are recorded and for landscapes where topography is complex and processes of cumulative runoff play a critical role in surface hydrological processes. The effect of the different land uses, tillage and management practices on the soil wetness status at monthly and annual intervals may also be considered in further research. Moreover, validation of the results of the new model against the moisture balance estimated by cropping simulators such as the CropSyst suite (Stöckle et al., 2004) is also considered for further research. Continuous assessment of the topsoil moisture status for each year will allow short-term monitoring of the changes in soil humidity. Moreover, the new model can be easily run under different climate change scenarios to assess the effects on the volume of water stored in the soil each month as well as the consequences on agricultural and environmental management and resources.

\section{Conclusions}

Time to ponding varies greatly between soil types and within the same soil type in the different seasons and months, according to the spatial and temporal variations of the 
antecedent topsoil moisture, maximum rainfall intensity and saturated hydraulic conductivity. When rainfall intensity is high (May, August, September and October), potential runoff is predicted for the whole catchment and its variability is very low, whereas areas with no runoff production appeared when rainfall intensity was low (average intensity between 5 and $9 \mathrm{~mm} \mathrm{~h}^{-1}$ ) and thus the variability of potential runoff was high. The spatial distribution of the different soil types is the main factor controlling the initiation of runoff, and to a lesser extent, the antecedent topsoil moisture and the volumetric content of water in the soil at saturation. Maps of effective cumulative runoff successfully draw the main flow paths in the study area and the numerous outlets that are associated with the lakes and the bottom of the different endorheic sub-catchments.

Maps of monthly actual available water after maximum rainfall intensity $\left(W_{a a}\right)$, soil moisture status $(S M S)$ and the Palmer Z-index draw similar spatial patterns, although the values and size of the different dry and wet categories vary considerably. Minimum $W_{a a}$ values are well correlated with average precipitation values; the mean values show close correlation with maximum rainfall intensity and maximum values are mainly controlled by overland flow accumulation processes. Four different scenarios of dryness and wetness are identified in the Estaña catchment during the year. Predominant wet conditions occur in May, September, October, November and December, and dry conditions appear in February, March and July. Each scenario is associated with different rainfall intensities and depths, topsoil moisture status, and dominant runoff generation and accumulation processes. The wettest conditions occur in gently sloping areas, in accordance with the wetness areas described by the topographic wetness index in the study area. Values obtained with the new DR2 model also reveal clear differences 
among the various soil types, where Vertisols and Regosols are the most humid and Calcisols and Leptosols the driest.

Palmer Z-index maps coincide very closely with the maps predicted by the new model between January and September, but very poorly between October and December. The spatial predictions from the DR2 model identify the different sub-categories of soil wetness with greater detail than Palmer's index, a feature of the new model being that it refines the method of assessing soil moisture status more accurately. Therefore, the DR2 model seems to be of interest to monitor humidity variations and trends in time and space in Mediterranean landscapes and can provide valuable information for sustainable soil and water resource management in agro-climatic analysis, especially in rain-fed productive agricultural systems. The technological development of GIS applications and the availability of detailed DEMs and datasets of soil properties support the use of this new model in numerous agricultural and natural areas.

\section{Acknowledgements}

This research was financially supported by the projects MEDEROCAR (CGL200800831/BTE) and EROMED (CGL2011-25486/BTE) funded by the Spanish Ministry of Science and Innovation. Dr. Manuel López-Vicente would also like to acknowledge the financial support of the Spanish Alfonso Martín Escudero Foundation for his postdoctoral stay during 2010 at K.U. Leuven, Belgium.

\section{References}

Balling Jr., R.C., 1996. Short communication: Century-long variations in United States drought severity. Agricultural and Forest Meteorology 82 (1-4), 293-299.

Beven, K.J., Kirkby, M.J., 1979. A physically based, variable contributing area model of basin hydrology. Hydrological Sciences Bulletin 24 (1), 43-69.

Borselli, L., Cassi, P., Torri, D., 2008. Prolegomena to sediment and flow connectivity in the landscape: A GIS and field numerical assessment. Catena 75 (3), 268-277. 
Ciais, P., Reichstein, M., Viovy, N., Granier, A., Ogee, J., Allard, V., Aubinet, M., Buchmann, N., Bernhofer, C., Carrara, A., Chevallier, F., De Noblet, N., Friend, A.D., Friedlingstein, P., Grunwald, T., Heinesch, B., Keronen, P., Knohl, A., Krinner, G., Loustau, D., Manca, G., Matteucci, G., Miglietta, F., Ourcival, J.M., Papale, D., Pilegaard, K., Rambal, S., Seufert, G., Soussana, J.F., Sanz, M.J., Schulze, E.D., Vesala, T., Valentini, R., 2005. Europe-wide reduction in primary productivity caused by the heat and drought in 2003. Nature 437 (7058), 529-533.

Cook, E.R., Woodhouse, C.A., Eakin, C.M., Meko, D.M., Stahle, D.W., 2004. Long-term aridity changes in the western United States. Science 306 (5698), 1015-1018.

Diodato, N., Bellocchi, G., 2008. Drought stress patterns in Italy using agro-climatic indicators. Climate Research 36 (1), 53-63.

Dracup, J.A., Lee, K.S., Paulson Jr., E.G., 1980a. On the Definition of Droughts. Water Resources Research 16 (2), 297-302.

Dracup, J.A., Lee, K.S., Paulson Jr., E.G., 1980b. On the statistical characteristics of drought indices. Water Resources Research 16 (2), 289-296.

Driessen, P.M., 1986. The water balance of soil. In: van Keulen, H., Wolf, J. (Eds.), Modeling of Agricultural Production: Weather, Soils and Crops. Pudoc, Wageningen, The Netherlands, pp. 76116.

Esteves, M., Descroix, L., Mathys, N., Lapetite, J.M., 2005. Soil hydraulic properties in a marly gully catchment (Draix, France). Catena 63 (2-3), 282-298.

Ghioca, M., 2009. Drought monitoring using self-calibrating Palmer's indices in the southwest of Romania. Romanian Reports in Physics 61 (1), 151-164.

Goy, J.L., Zazo, C., Dabrio, C.J., 2003. A beach-ridge progradation complex reflecting periodical sealevel and climate variability during the Holocene (Gulf of Almería, Western Mediterranean). Geomorphology 50 (1-3), 251-268.

Grabs, T., Seibert, J., Bishop, K., Laudon, H., 2009. Modeling spatial patterns of saturated areas: A comparison of the topographic wetness index and a dynamic distributed model. Journal of Hydrology $373(1-2), 15-23$.

Heim, R.R., 2002. A review of twentieth-century drought indices used in the United States. Bulletin of the American Meteorological Society 83 (8), 1149-1165.

Hogarth, W.L., Sardana, V., Watson, K.K., Sander, G.C., Parlange, J.Y., Haverkamp, R., 1991. Testing of approximate expression for soil water status at the surface during infiltration. Water Resources Research 27 (8), 1957-1961.

Hu, Q., Willson, G.D., 2000. Effects of temperature anomalies on the Palmer Drought Severity Index in the Central United States. International Journal of Climatology 20 (15), 1899-1911.

Julien, P.Y., Saghafian, B., 1991. CASC2D User's Manual - A Two Dimensional Watershed RainfallRunoff Model. Department of Civil Engineering, Colorado State University, Fort Collins, Colorado. Report CER90-91PYJ-BS-12. 66 pp.

Karl, T.R., 1986. The Sensitivity of the Palmer Drought Severity Index and Palmer's Z-Index to their Calibration Coefficients Including Potential Evapotranspiration. Journal of Climate and Applied Meteorology 25 (1), 77-86. 
Lal, R., 2008. Managing soil water to improve rainfed agriculture in India. Journal of Sustainable Agriculture 32 (1), 51-75.

Latron, J., Gallart, F., 2008. Runoff generation processes in a small Mediterranean research catchment (Vallcebre, Eastern Pyrenees). Journal of Hydrology 358 (3-4), 206-220.

López-Vicente, M., Navas, A., 2009. Predicting soil erosion with RUSLE in Mediterranean agricultural systems at catchment scale. Soil Science 174 (5), 272-282.

López-Vicente, M., Navas, A., 2010. Routing runoff and soil particles in a distributed model with GIS: implications for soil protection in mountain agricultural landscapes. Land Degradation and Development 21 (2), 100-109.

López-Vicente, M., Navas, A., Machín, J., 2008. Identifying erosive periods by using RUSLE factors in mountain fields of the Central Spanish Pyrenees. Hydrology and Earth System Sciences 12 (2), 523535.

López-Vicente, M., Navas, A., Machín, J., 2009a. Geomorphic mapping in endorheic subcatchments in the Spanish Pyrenees: an integrated GIS analysis of topographic-karstic features. Geomorphology $111(1-2), 38-47$.

López-Vicente, M., Navas, A., Machín, J., 2009b. The effect of physiographic conditions on the spatial variation of seasonal topsoil moisture in Mediterranean soils. Australian Journal of Soil Research 47 (5), 498-507.

López-Vicente, M., Nelson, R., Stockle, C.O., Navas, A., Machín, J., 2005. Modelización de la capacidad de transporte distribuida en subcuencas endorreicas del Pirineo oscense (Modelling distributed transport capacity in endorheic subcatchments of the Spanish Pyrenees). In: Proceedings of the II Simposio Nacional Sobre Control de la Degradación de Suelos, Madrid, Spain, pp. 813-817.

Machín, J., López-Vicente, M., Navas, A., 2008. Cartografía digital de suelos de la Cuenca de Estaña (Prepirineo Central). In “Trabajos de Geomorfología en España, 2006-2008”. (Eds J Benavente, FJ Gracia) (In Spanish) pp. 481-484. (SEG: Cádiz, Spain).

Mallick, K., Bhattacharya, B.K., Patel, N.K., 2009. Estimating volumetric surface moisture content for cropped soils using a soil wetness index based on surface temperature and NDVI. Agricultural and Forest Meteorology 149 (8), 1327-1342.

Morellón, M., Valero-Garcés, B., González-Sampériz, P., Vegas-Vilarrúbia, T., Rubio, E., Rieradevall, M., Delgado-Huertas, A., Mata, P., Romero, O., Engstrom, D.R., López-Vicente, M., Navas, A., Soto, J., 2009. Climate changes and human activities recorded in the sediments of Lake Estanya (NE Spain) during the Medieval Warm Period and Little Ice Age. Journal of Paleolimnology, DOI 10.1007/s10933-009-9346-3.

Morellón, M., Valero-Garcés, B., Moreno, A., González-Sampériz, P., Mata, P., Romero, O., Maestro, M., Navas, A., 2008. Holocene palaeohydrology and climate variability in northeastern Spain: The sedimentary record of Lake Estanya (Pre-Pyrenean range). Quaternary International 181, 15-31.

Palmer, W.C., 1965. Meteorological drought. Office of Climatology, research paper no. 45, U.S. Weather Bureau, 58. 
Renard, K.G., Foster, G.R., Weesies, G.A., McCool, D.K., Yoder, D.C., 1997. Predicting Soil Erosion by Water: A Guide to Conservation Planning with the Revised Universal Soil Loss Equation (RUSLE). Handbook \#703. US Department of Agriculture, Washington, DC.

Sørensen, R., Zinko, U., Seibert. J., 2006. On the calculation of the topographic wetness index: evaluation of different methods based on field observations. Hydrology and Earth System Sciences 10 (1), 101112.

Spadavecchia, L., Williams, M., 2009. Can spatio-temporal geostatistical methods improve high resolution regionalisation of meteorological variables? Agricultural and Forest Meteorology 149 (67), 1105-1117.

Stöckle, C.O., Kjelgaard, J., Bellocchi G., 2004. Evaluation of estimated weather data for calculating Penman-Monteith reference crop evapotranspiration. Irrigation Science 23 (1), 39-46.

Thomas, R.J., 2008. Opportunities to reduce the vulnerability of dryland farmers in Central and West Asia and North Africa to climate change. Agriculture Ecosystems \& Environment 126 (1-2), 36-45.

Trnka, M., Dubrovský, M., Svoboda, M., Semerádová, D., Hayes, M., Žalud, Z., Wilhite, D., 2009 a. Developing a regional drought climatology for the Czech Republic. International Journal of Climatology 29 (6), 863-883.

Trnka, M., Kyselý, J., Možný M., Dubrovský, M., 2009b. Changes in Central-European soil-moisture availability and circulation patterns in 1881-2005. International Journal of Climatology 29 (5), 655672.

Vicente-Serrano, S.M., 2007. Evaluating the impact of drought using remote sensing in a Mediterranean, semi-arid region. Natural Hazards 40 (1), 173-208.

Vicente-Serrano, S.M., López-Moreno, J.I., Drumond, A., Gimeno, L., Nieto, R., Morán-Tejeda, E., Lorenzo-Lacruz, J., Beguería, S., Zabalza, J., 2011. Effects of warming processes on droughts and water resources in the NW Iberian Peninsula (1930-2006). Climate Research 48 (2-3), 203-212.

Wang, Q.X., Takahashi, H., 1999. A land surface water deficit model for an arid and semiarid region: Impact of desertification on the water deficit status in the Loess Plateau, China. Journal of Climate 12 (1), 244-257.

White, I., Sully, M.J., 1989. Use and Hydrological Robustness of Time-to-Incipient-Ponding. Soil Science Society of America Journal 53, 1343-1346.

Wilhite, D.A., Glantz, M.H., 1985. Understanding the drought phenomenon: The role of definitions. Water International $10(3), 111-120$.

World Meteorological Organization, 1975. Drought and agriculture. WMO Note 138, Publ. WMO-392, Geneva, Switzerland, 127 pp.

Zhongmin, H., Guirui, Y., Yanlian, Z., Xiaomin, S., Yingnian, L., Peili, S., Yanfen, W., Xia, S., Zemei, Z., Li, Z., Shenggong, L., 2009. Partitioning of evapotranspiration and its controls in four grassland ecosystems: Application of a two-source model. Agricultural and Forest Meteorology 149 (9), 14101420. 
Figure 1 Geographic situation of the Estaña catchment in NE Spain (a); annual precipitation (b); and monthly rainfall, potential reference evapotranspiration and minimum and maximum temperature (c).
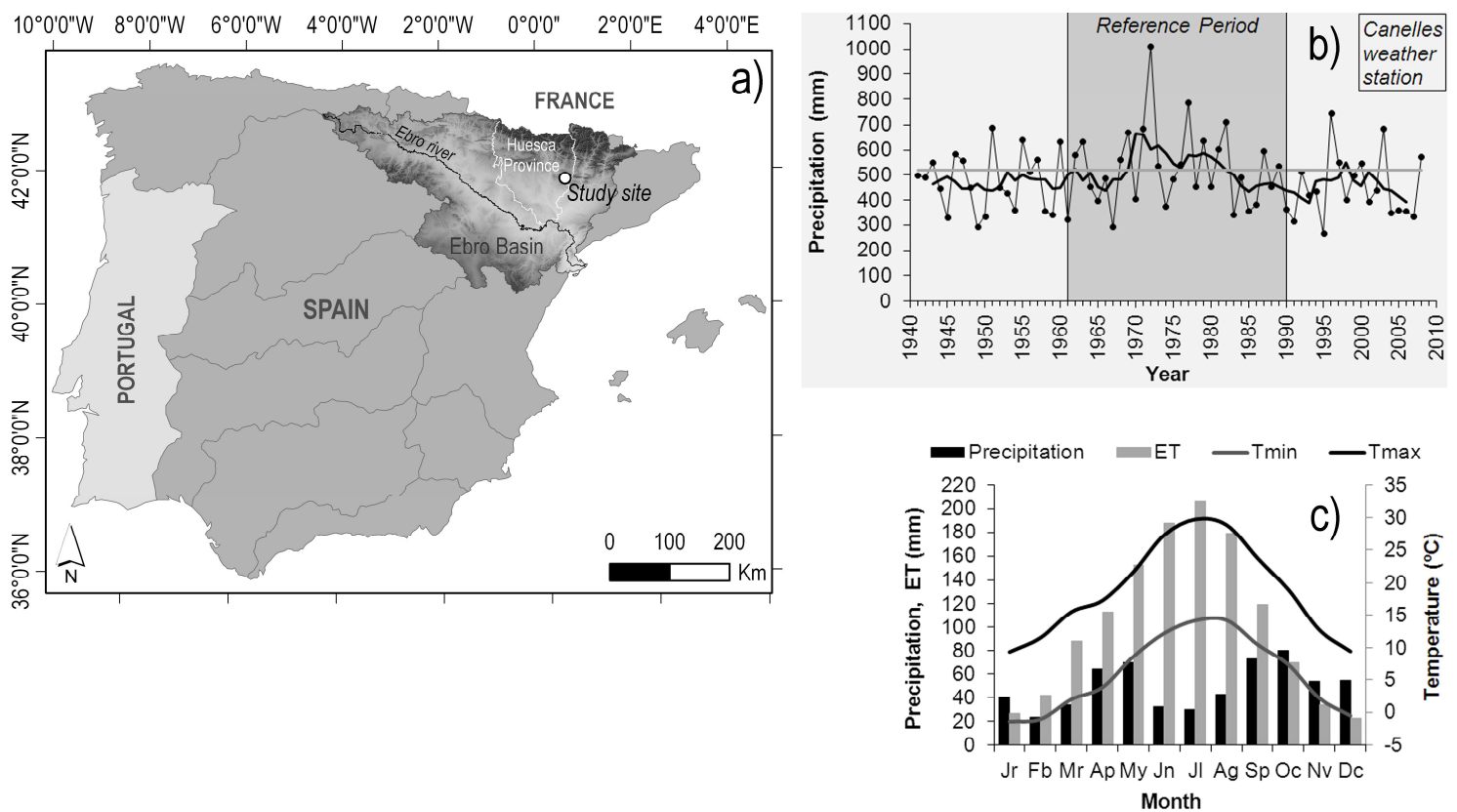
Figure 2 Step-by-step procedure to estimate the actual available water $\left(W_{a a}\right)$ at pixel scale.

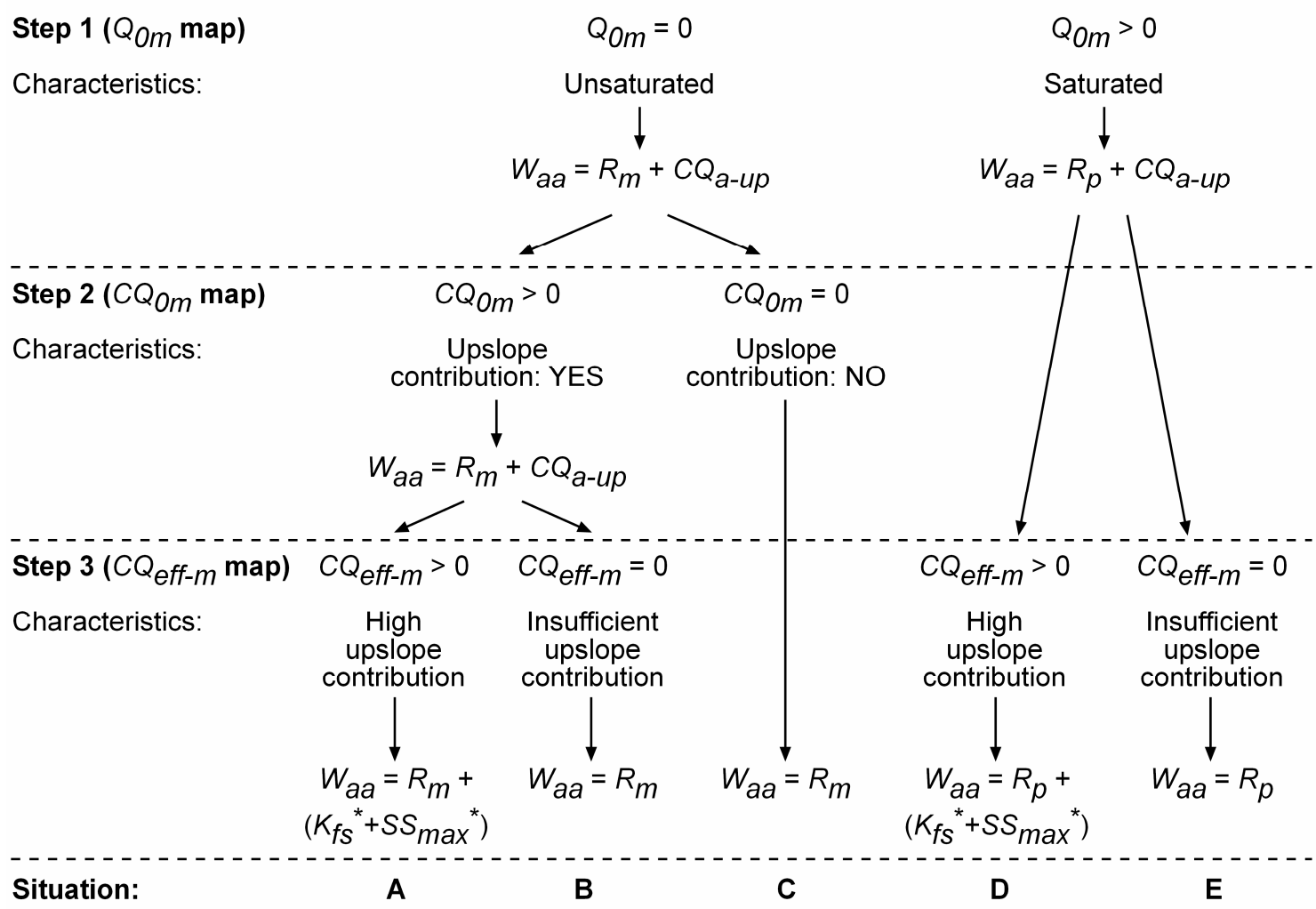

$Q_{o m}$ : potential runoff per raster cell; $R_{m}$ : monthly rainfall; $C Q_{a-u p}$ : available upslope cumulative runoff; $R_{p}$ : rainfall to ponding; $C Q_{o m}$ : monthly potential cumulative runoff; $C Q_{e f f-m}$ : monthly effective cumulative runoff; $K_{f s}{ }^{*}$ : saturated hydraulic conductivity $\left(K_{f s} T q_{m} e_{m}\right.$, see Eq. (6)); $S S^{*}$ : maximum surface storage capacity $\left(S S_{\max } e_{m}\right.$, see Eq. (6)). 
Figure 3 Maps of the antecedent topsoil moisture content $\left(\theta_{0}, \% \mathrm{Vol}\right)$ in May, August, December and February in the Estaña catchment (NE Spain).
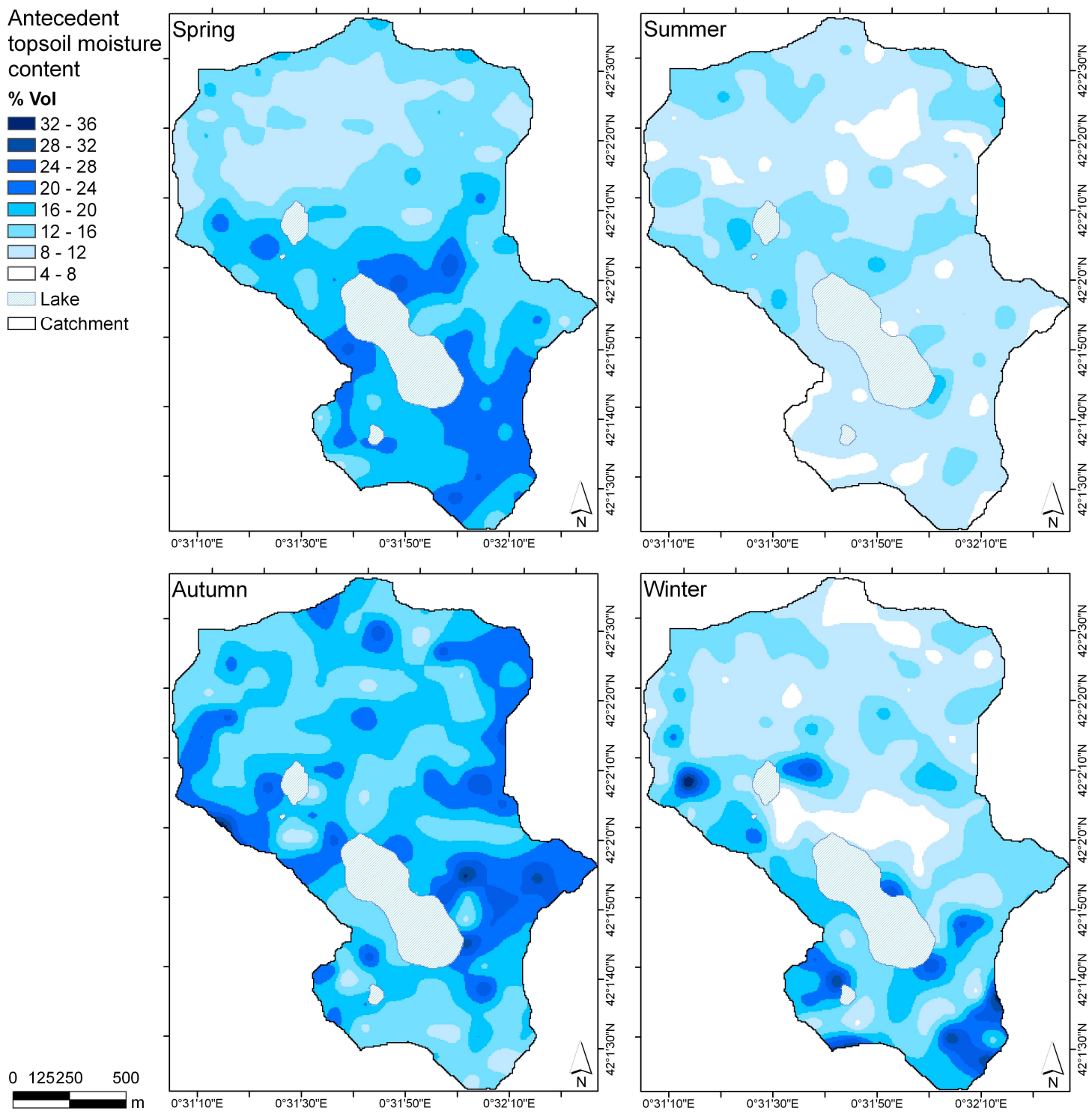
Figure 4 Average runoff coefficients estimated for the whole study area and soil type in the Estaña catchment (NE Spain) for each month of the year after the maximum rainfall intensity.

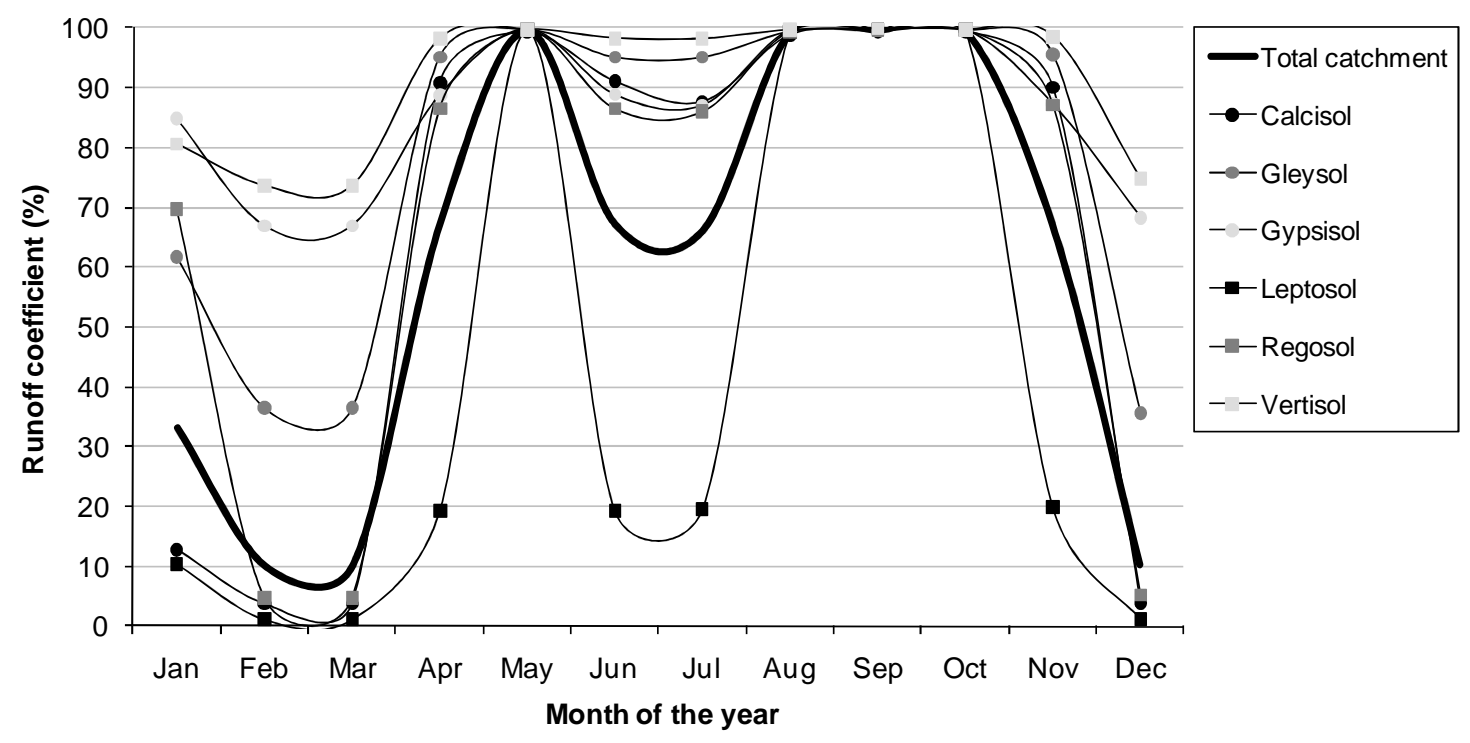


Figure 5 Maps of effective cumulative runoff $\left(C Q_{e f f}\right)$ predicted on monthly basis at the Estaña catchment (NE Spain).

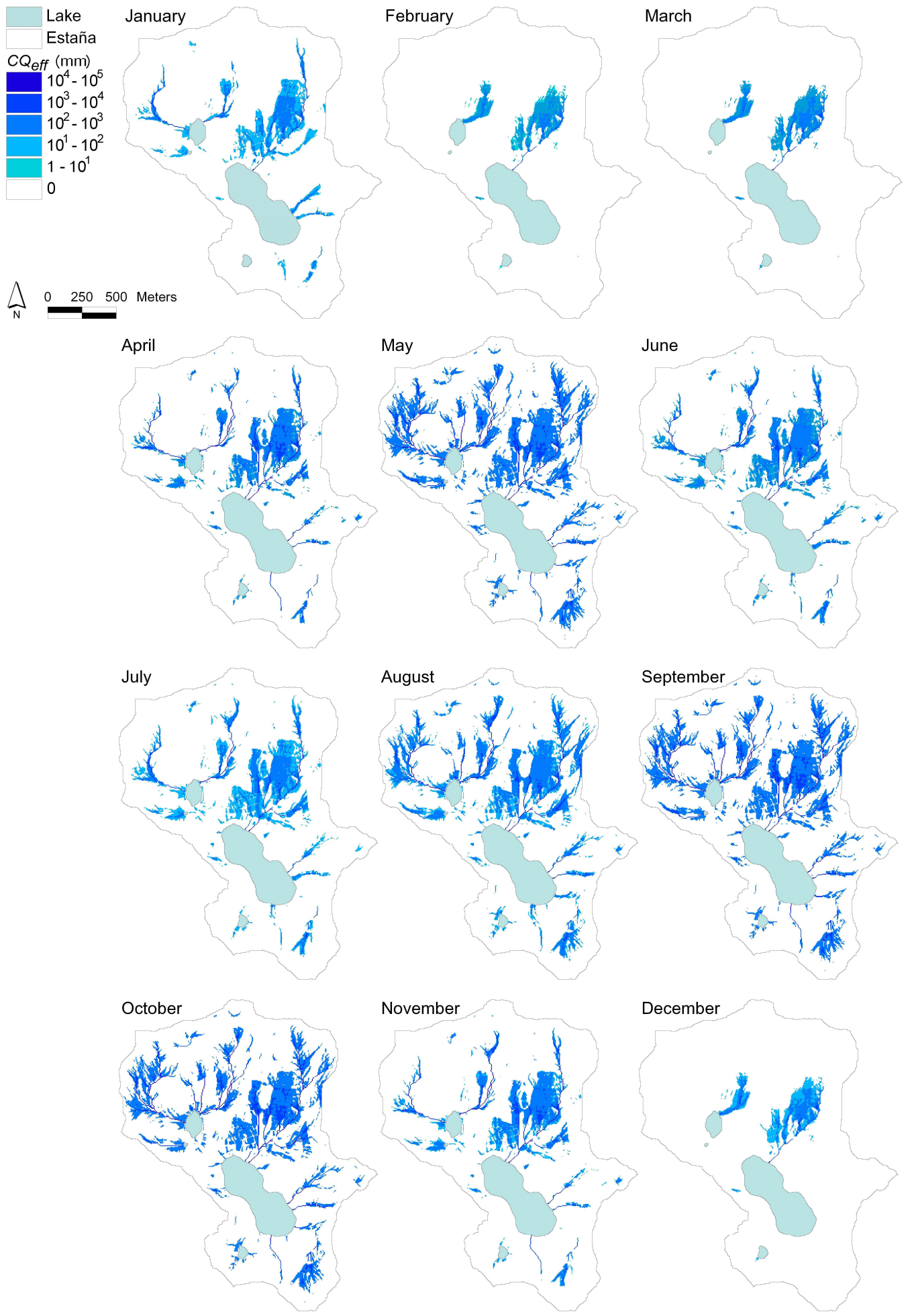


Figure 6 Maps of actual available water $\left(W_{a a}\right)$ in the Estaña catchment (NE Spain) at monthly scale after the maximum rainfall intensity.

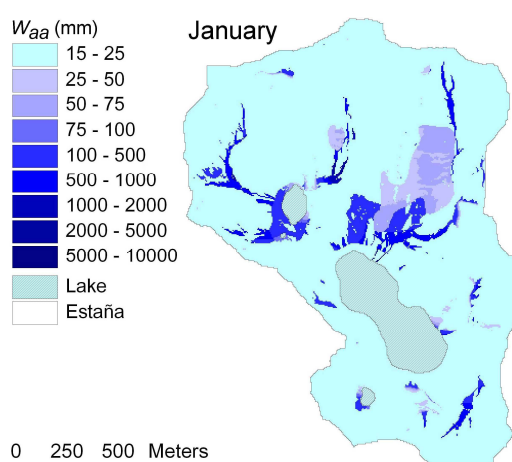

250500 Meters
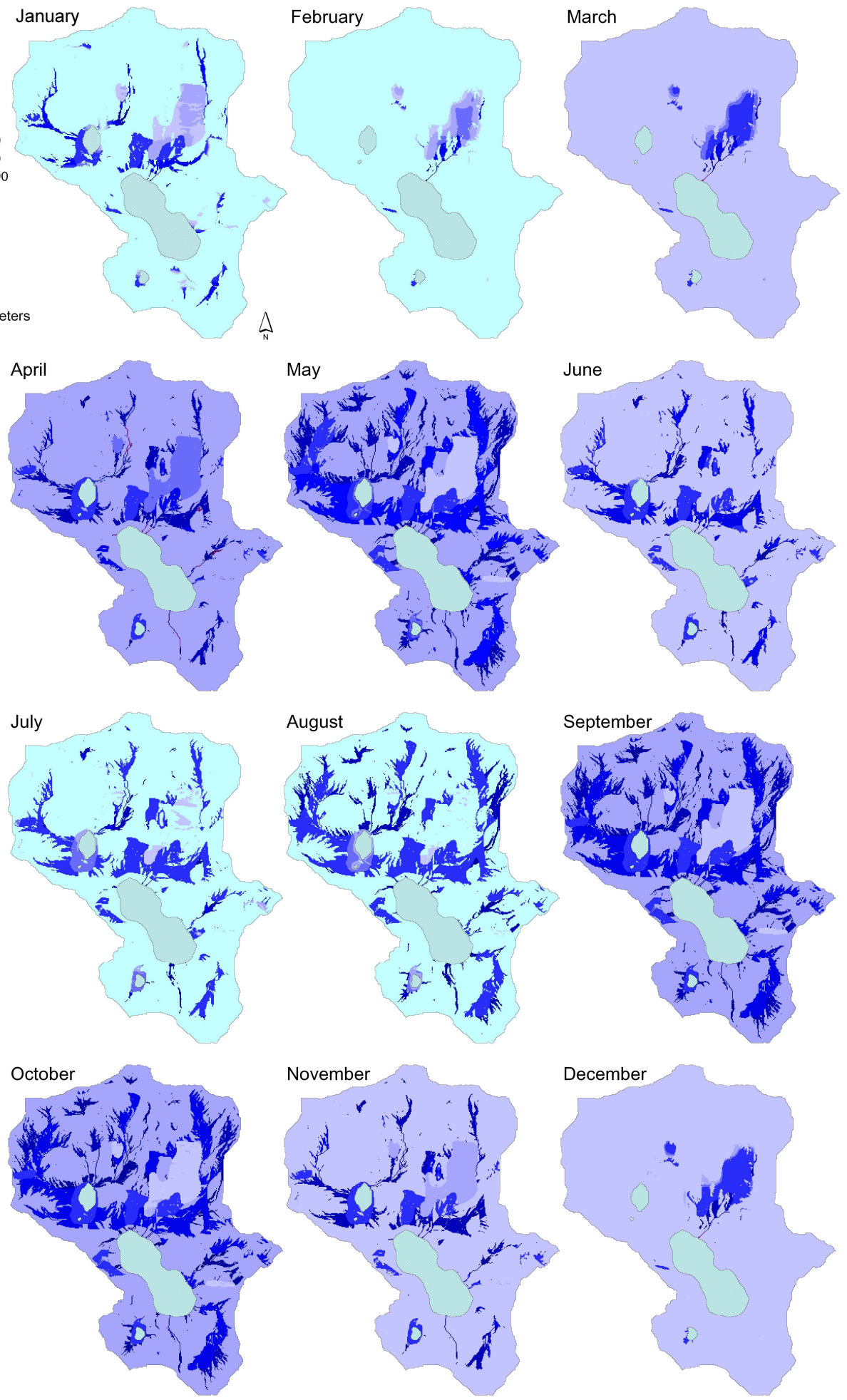
Figure 7 Maps of the soil moisture status (SMS) for each month of the year after the maximum rainfall intensity and maps of the topographic wetness index (TWI) and soil types in the Estaña catchment (NE Spain).
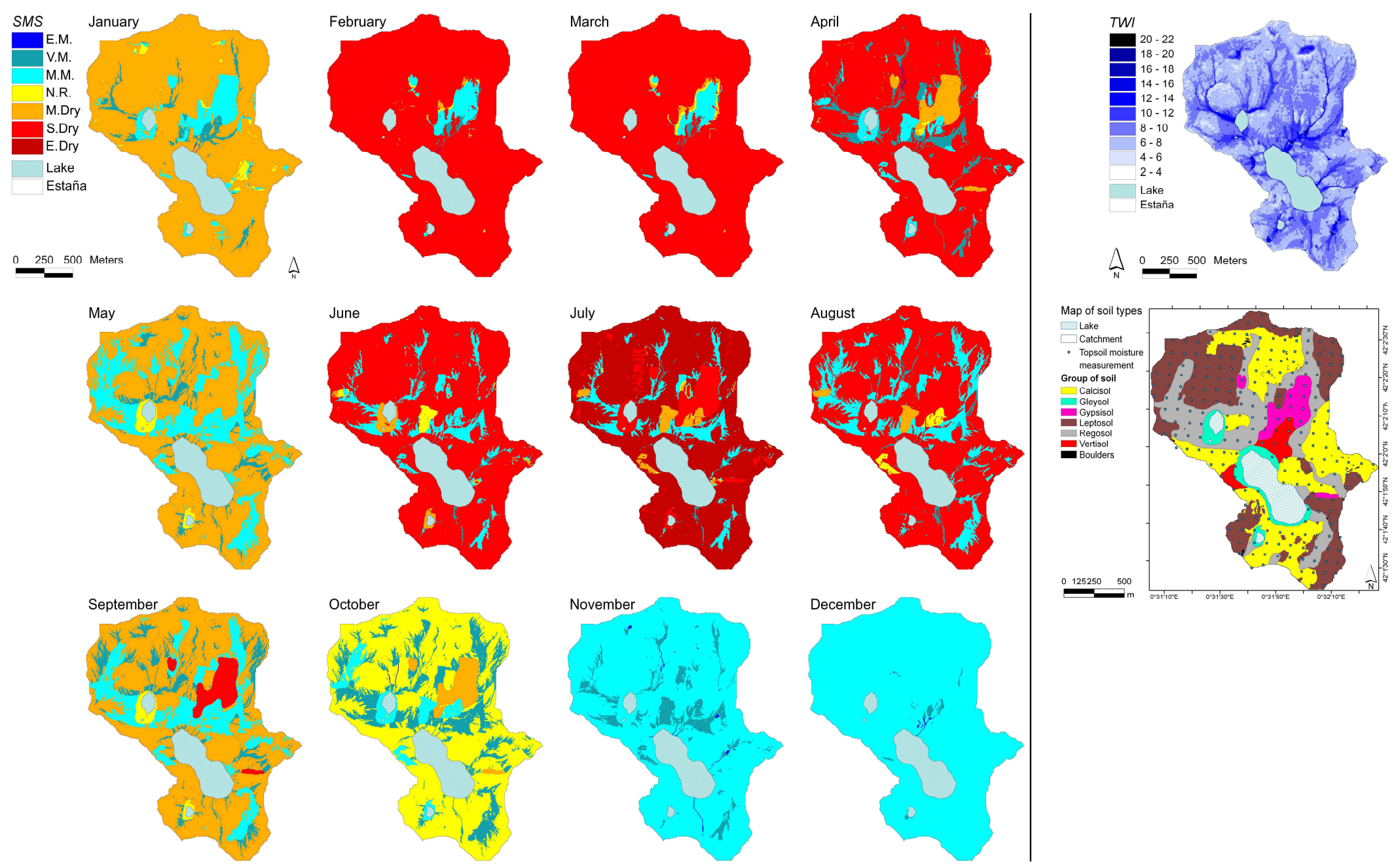

E.M.: extremely moist; V.M.: very moist; M.M.: moderately moist; N.R.: normal range; M.D.: moderately dry; S.D.: severely dry; E.D.: extremely dry 
Figure 8 Monthly percentage of the surface of the Estaña catchment (NE Spain) under different humidity status estimated from the maps of the DR2 model for the different topographic conditions.

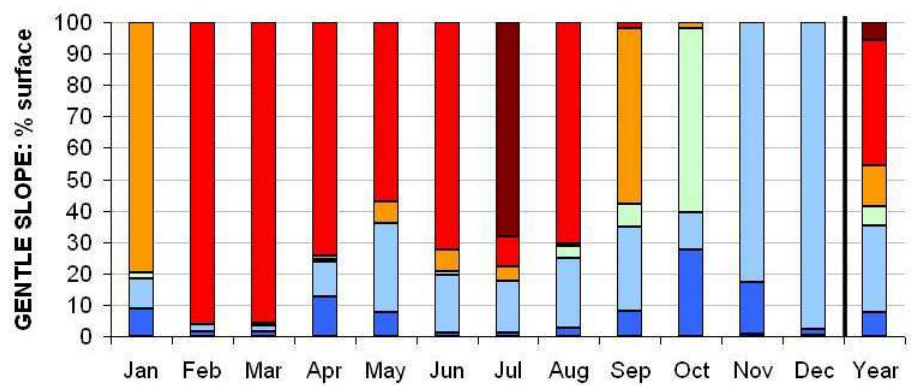

\section{E.D. $\square S . D$. \\ Topographic trend:} $\square$ M.D. $\square$ N.R. $\square \mathrm{M} . \mathrm{M}$. $\square$ V.M.

$\square$ E.M.
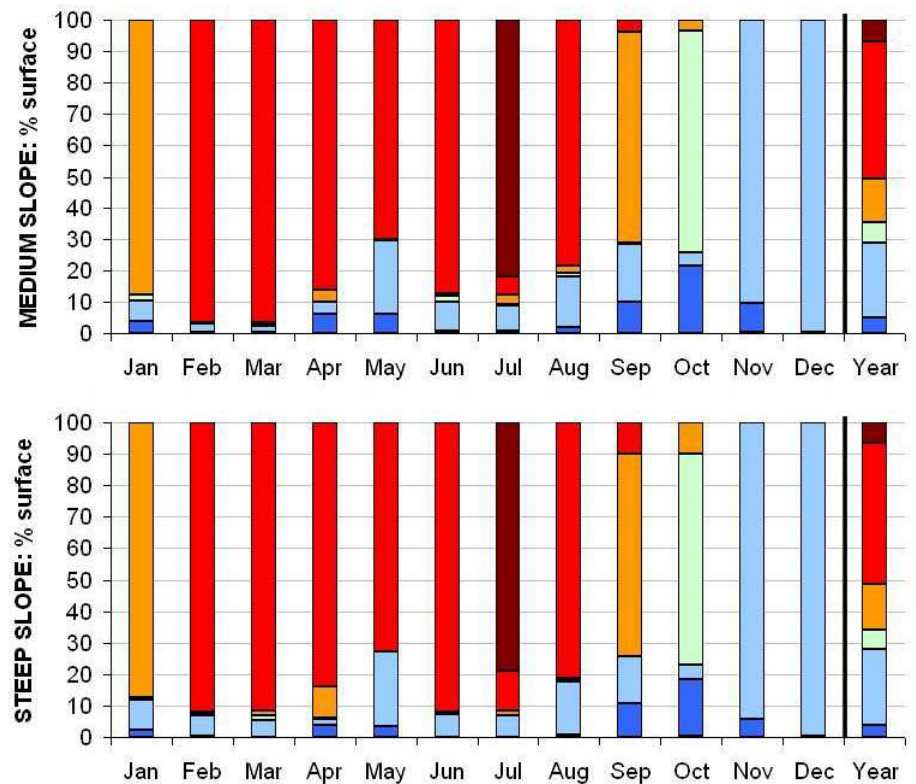

Wetter

\section{Drier}

E.D.: extremely dry; S.D.: severely dry; M.D.: moderately dry; N.R.: normal range; M.M.: moderately moist; V.M.: very moist; E.M.: extremely moist 
Figure 9 Monthly percentage of the surface of the Estaña catchment (NE Spain) under different humidity status estimated from the maps of the DR2 model for the different soil types.
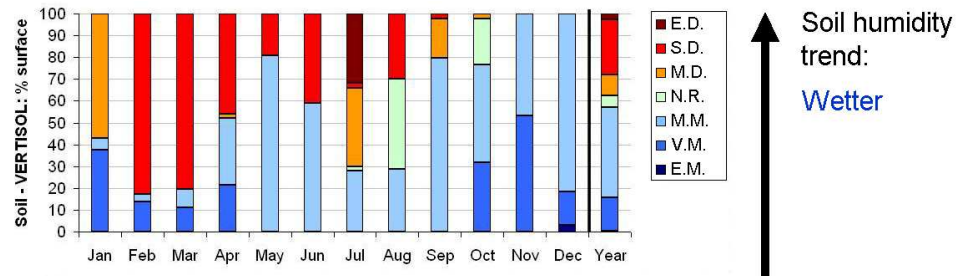

N.R.

M.M.

Wetter
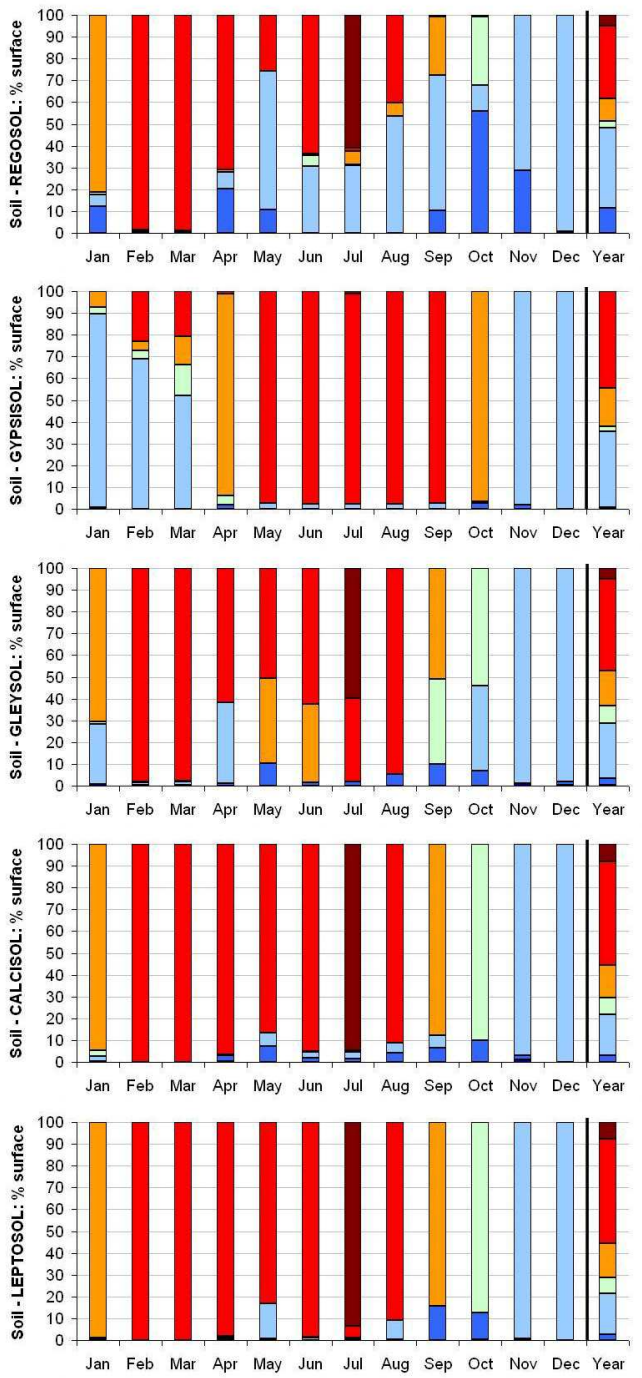

Drier

E.D.: extremely dry; S.D.: severely dry; M.D.: moderately dry; N.R.: normal range; M.M.: moderately moist; V.M.: very moist; E.M.: extremely moist 
Figure 10 Maps of the Palmer Z-index of soil dryness-wetness in the Estaña catchment (NE Spain) for each month of the year after the maximum rainfall intensity.

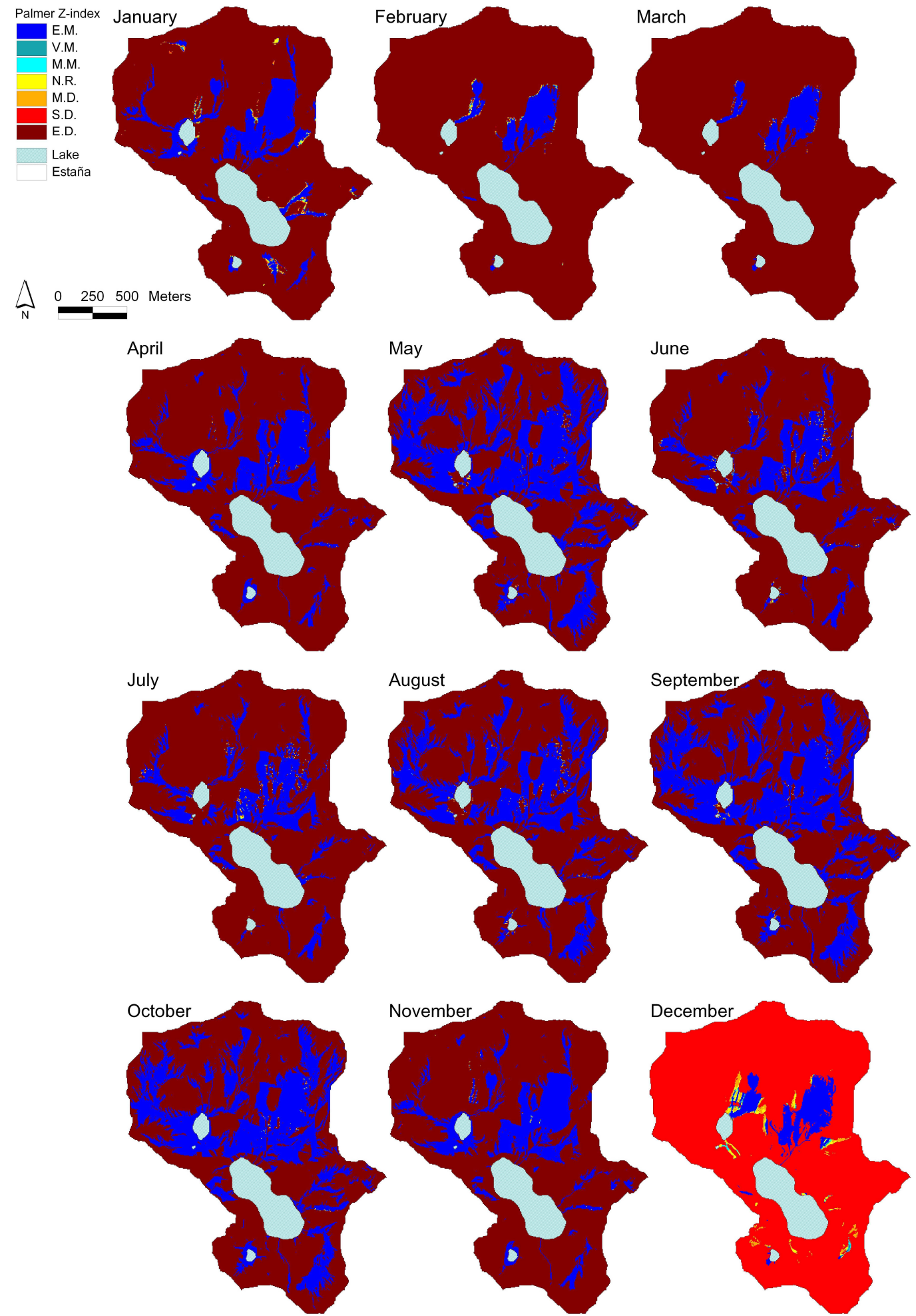

E.M.: extremely moist; V.M.: very moist; M.M.: moderately moist; N.R.: normal range; M.D.: moderately dry; S.D.: severely dry; E.D.: extremely dry 
Figure 11 Percentage of the study area under different humidity status estimated with the new DR2 model and calculated with the Palmer Z-index for each month of the year after the maximum rainfall intensity.

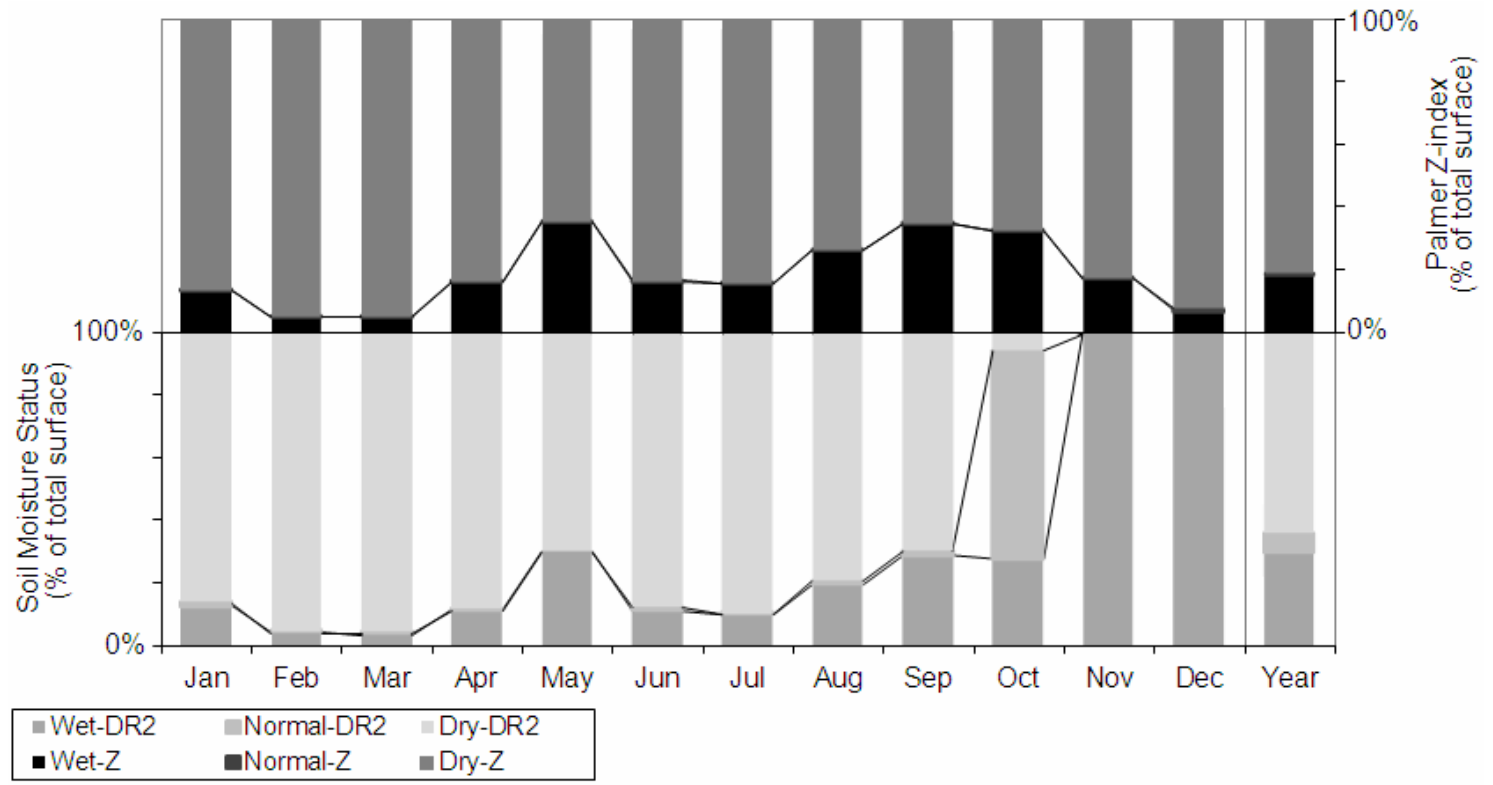


Table 1 Classes for wet and dry periods according to Palmer (1965).

\begin{tabular}{cll}
\hline Z-index value & & Drought index categories \\
\cline { 1 - 1 } 2.50 to 3.49 & & Very moist \\
1.00 to 2.49 & & Moderately moist \\
-1.24 to 0.99 & & Normal range \\
-1.25 to -1.99 & & Moderately dry \\
-2.00 to -2.74 & & Severely dry \\
$\leq-2.75$ & Extremely dry
\end{tabular}


Table 2 Estimated average time to ponding for the different soil types in the Estaña catchment (NE Spain) for each month of the year. $R$ : Rainfall; $e$ : number of erosive events; $I_{30 \text { mean }}$ : average value of maximum rainfall intensity in 30 minutes; $I_{30 \max }$ : maximum rainfall intensity in 30 minutes; $n$ : number of soil samples; NP: No ponding; ${ }^{*}$ : values from the Canelles weather station

\begin{tabular}{|c|c|c|c|c|c|c|c|c|c|c|c|c|c|c|c|c|}
\hline \multirow[t]{3}{*}{ Month } & \multirow{3}{*}{$\begin{array}{c}R^{*} \\
\mathrm{~mm}\end{array}$} & \multirow{3}{*}{$\begin{array}{l}e^{*} \\
\mathrm{n}\end{array}$} & \multirow{3}{*}{\multicolumn{2}{|c|}{$\begin{array}{c}I_{30 \text { mean }}{ }^{*} I_{30 \max } \\
\mathrm{mm} \mathrm{h}^{-1}\end{array}$}} & \multicolumn{12}{|c|}{ Time to ponding $(T p, \mathrm{~s})$} \\
\hline & & & & & \multicolumn{2}{|c|}{ Calcisol $(n=79)$} & \multicolumn{2}{|c|}{ Gleysol $(n=7)$} & \multicolumn{2}{|c|}{ Gypsisol $(n=9)$} & \multicolumn{2}{|c|}{ Leptosol $(n=82)$} & \multicolumn{2}{|c|}{ Regosol $(n=51)$} & \multicolumn{2}{|c|}{ Vertisol $(n=8)$} \\
\hline & & & & & $I_{30 \text { mean }}$ & $I_{30 \max }$ & $I_{30 \text { mean }}$ & $I_{30 \max }$ & $I_{30 \text { mean }}$ & $I_{30 \max }$ & $I_{30 \text { mean }}$ & $I_{30 \max }$ & $I_{30 \text { mean }}$ & $I_{30 \max }$ & $I_{30 \text { mean }}$ & $I_{30 \max }$ \\
\hline Jan & 18.7 & 6.4 & 6.6 & 15.4 & NP & NP & 2.0 & 0.8 & 0.6 & 0.2 & NP & NP & NP & 7.9 & 8.2 & 0.8 \\
\hline $\mathrm{Feb}$ & 15.6 & 2.7 & 7.1 & 7.8 & NP & $\mathbf{N P}$ & 1.8 & 1.6 & 0.5 & 0.5 & NP & NP & NP & NP & 5.0 & 3.3 \\
\hline Mar & 27.5 & 6.5 & 5.7 & 9.2 & NP & NP & 2.3 & 1.3 & 0.7 & 0.4 & NP & NP & NP & NP & NP & 2.1 \\
\hline Apr & 53.7 & 8.7 & 10.9 & 24.6 & NP & 13.5 & 0.9 & 0.4 & 0.3 & 0.2 & NP & NP & NP & 2.8 & 1.2 & 0.4 \\
\hline May & 56.3 & 8.8 & 15.4 & 69.8 & NP & 2.6 & 0.6 & 0.1 & 0.2 & 0.1 & NP & 0.5 & 7.3 & 0.7 & 0.7 & 0.1 \\
\hline Jun & 28.0 & 4.7 & 17.9 & 31.2 & 47.7 & 8.2 & 0.5 & 0.3 & 0.2 & 0.1 & NP & NP & 5.0 & 1.9 & 0.5 & 0.3 \\
\hline Jul & 19.8 & 4.4 & 21.8 & 32.6 & 21.4 & 8.7 & 0.6 & 0.4 & 0.2 & 0.1 & NP & NP & 3.7 & 2.0 & 0.4 & 0.3 \\
\hline Aug & 25.9 & 5.3 & 19.8 & 43.6 & 30.8 & 5.5 & 0.6 & 0.3 & 0.2 & 0.1 & NP & 1.5 & 4.5 & 1.4 & 0.5 & 0.2 \\
\hline Sep & 60.5 & 5.9 & 26.9 & 65.6 & 12.6 & 3.2 & 0.5 & 0.2 & 0.1 & 0.1 & NP & 0.5 & 2.6 & 0.8 & 0.3 & 0.1 \\
\hline Oct & 66.2 & 8.5 & 17.2 & 57.8 & 60.2 & 2.8 & 0.6 & 0.2 & 0.2 & 0.1 & NP & 0.6 & 5.1 & 0.8 & 0.5 & 0.1 \\
\hline Nov & 40.3 & 6.9 & 8.6 & 25.0 & NP & 11.2 & 1.2 & 0.4 & 0.4 & 0.1 & NP & NP & NP & 2.5 & 1.8 & 0.3 \\
\hline Dec & 35.0 & 4.7 & 5.4 & 9.0 & NP & NP & 2.1 & 1.2 & 0.7 & 0.4 & NP & NP & NP & NP & NP & 1.6 \\
\hline
\end{tabular}


Table 3 Classes for wet and dry conditions for the soil moisture status (SMS) of the DR2 model.

\begin{tabular}{cll}
\hline \multicolumn{1}{c}{$S M S$ value } & & Wetness-Drought \\
\cline { 1 - 1 } 10 to 100 & & Extremely moist \\
1.1 to 10 & & Moderately moist \\
0.9 to 1.1 & Normal range \\
0.5 to 0.9 & & Moderately dry \\
0.1 to 0.5 & Severely dry \\
0 to 0.1 & Extremely dry
\end{tabular}


Table 4 Summarize of the average values of saturated hydraulic conductivity $\left(K_{f s}\right)$ and sorptivity $\left(S_{p}\right)$ (taken from López-Vicente and Navas, 2009$)$, volumetric water content at saturation $\left(\theta_{S}\right)$ and initial $\left(\theta_{0}\right)$ conditions, soil moisture status $(S M S)$ and Palmer $Z$-index for the main soil types in the Estaña catchment (NE Spain).

\begin{tabular}{|c|c|c|c|c|c|c|c|}
\hline \multirow[t]{3}{*}{ Soil type } & \multirow[t]{3}{*}{ Season } & \multicolumn{2}{|c|}{ Infiltration } & \multicolumn{2}{|c|}{ Soil moisture } & \multirow{3}{*}{$\begin{array}{l}S M S \\
\text { mean }\end{array}$} & Palmer Z-index \\
\hline & & $K_{f s}$ & $S_{p}$ & $\theta_{S}$ & $\theta_{0}$ & & mean \\
\hline & & $\left(\mathrm{cm} \mathrm{s}^{-1}\right)$ & $\left(\mathrm{cm} \mathrm{s}^{-0.5}\right)$ & (\% vol.) & (\% vol.) & & \\
\hline \multirow[t]{4}{*}{ Calcisol } & Spring & 0.000443 & 0.0866 & 43.0 & 14.6 & 1.5 & 6.6 \\
\hline & Summer & & 0.0741 & & 10.1 & 1.5 & 6.5 \\
\hline & Autumn & & 0.0648 & & 18.0 & 3.6 & 6.4 \\
\hline & Winter & & 0.0686 & & 14.0 & 0.5 & 6.9 \\
\hline \multirow[t]{4}{*}{ Leptosol } & Spring & 0.000948 & 0.0299 & 46.6 & 12.9 & 0.9 & 6.6 \\
\hline & Summer & & 0.0299 & & 10.3 & 1.2 & 6.5 \\
\hline & Autumn & & 0.0265 & & 17.7 & 2.6 & 6.3 \\
\hline & Winter & & 0.0281 & & 13.5 & 0.5 & 7.0 \\
\hline \multirow[t]{4}{*}{ Regosol } & Spring & 0.000304 & 0.0472 & 51.6 & 14.8 & 3.0 & 4.2 \\
\hline & Summer & & 0.0468 & & 11.6 & 2.6 & 3.6 \\
\hline & Autumn & & 0.0436 & & 17.6 & 7.5 & 4.6 \\
\hline & Winter & & 0.0464 & & 12.3 & 1.8 & 6.5 \\
\hline
\end{tabular}

